Canadian University Music Review

Revue de musique des universités canadiennes

\title{
Music and Text in Elisabeth Lutyens's Wittgenstein Motet
}

\section{Laurel Parsons}

Volume 20, numéro 1, 1999

URI : https://id.erudit.org/iderudit/1015648ar

DOI : https://doi.org/10.7202/1015648ar

Aller au sommaire du numéro

Éditeur(s)

Canadian University Music Society / Société de musique des universités canadiennes

ISSN

0710-0353 (imprimé)

2291-2436 (numérique)

Découvrir la revue

Citer cet article

Parsons, L. (1999). Music and Text in Elisabeth Lutyens's Wittgenstein Motet. Canadian University Music Review / Revue de musique des universités

canadiennes, 20(1), 71-100. https://doi.org/10.7202/1015648ar
Résumé de l'article

Although Elisabeth Lutyens (1906-83) was a pioneer of British twentieth-century music, her work is relatively unknown in North America. This article begins with an introduction to her life and compositions, before going on to a detailed analysis of text-music relations in selected passages of her Motet, op. 27 (1953). The analysis forms the basis for a discussion of the concept of text as representation of music: Lutyens began to compose the music of the Motet first, and chose its text-excerpts from the Tractatus logico-philosophicus (1921) by the Austrian-born English philosopher Ludwig Wittgenstein (1889-1951)—because it seemed a fitting expression of the musical ideas that had already begun to develop.
All Rights Reserved (C Canadian University Music Society / Société de musique des universités canadiennes, 2000
Ce document est protégé par la loi sur le droit d'auteur. L'utilisation des services d'Érudit (y compris la reproduction) est assujettie à sa politique d'utilisation que vous pouvez consulter en ligne.

https://apropos.erudit.org/fr/usagers/politique-dutilisation/ 


\section{MUSIC AND TEXT IN ELISABETH LUTYENS'S WITTGENSTEIN MOTET ${ }^{1}$}

\section{Laurel Parsons}

"I know from experience that sanity ... lies in applying the conscious mind objectively and allowing the 'unconscious'- 'inspiration', 'soul', 'spirit' ... to look, as an adult, after itself." 2 This remark, made early in her career by the British composer Elisabeth Lutyens (1906-83), is echoed in her insistence throughout her life that art was "a precision instrument." Nowhere in the corpus of Lutyens's work is this philosophy more apparent than in her twelve-tone Motet, op. 27 (1953), based on the Tractatus logico-philosophicus (1921), the landmark treatise by the Austrian-born English philosopher Ludwig Wittgenstein (1889-1951). One intriguing aspect of this beautifully constructed work is the relationship between its text and musical structure, and it is on this relationship that the main, analytical body of this paper will focus. But first, given Lutyens's relative obscurity in North America, some biographical context is in order.

\section{BIOGRAPHICAL BACKGROUND}

The compositions of Elisabeth Lutyens have yet to become as well-known as the legendary personality of a woman who surely must be counted among the most fascinating of twentieth-century British composers. The fourth child of Lady Emily Lytton and the renowned architect Sir Edwin Lutyens, she came from a long line of artists and eccentrics, including her great-grandfather, the Gothic novelist and statesman Sir Edward George Bulwer-Lytton, author of The Last Days of Pompeii (1834) and Rienzi (1835), and her grandfather Sir Robert Lytton, Viceroy of India (1875-80), poet and avid roller-skater. Her mother, Lady Emily, a childhood friend of Virginia Woolf, carried on the tradition of idiosyncrasy in her own way, as an early twentieth-century champion of the cult of theosophy, which at the time held that the young Krishnamurti was the new messiah. When Krishnamurti came to England in

1 This is a revised version of a paper presented at the 1998 conference of the Canadian University Music Society in Ottawa, where it was awarded the George Proctor Prize jointly with Nancy Berman's paper entitled "From Le sacre to Les noces: Primitivism and the Changing Face of Modernity," also published in this issue.

2Elisabeth Lutyens, cited in Meirion and Susie Harries, A Pilgrim Soul: The Life and Work of Elisabeth Lutyens (London: Michael Joseph, 1989), 52 (emphasis in original). This source provides the most complete published account of Lutyens's life and career. Also of importance is Lutyens's autobiography A Goldfish Bowl (London: Cassell, 1972). These two sources will be referred to in the remainder of this paper as $A P S$ and $A G B$, respectively. 
1911 to attend university, the adoring Lady Emily unofficially adopted him into the Lutyens household, and for the next ten years, her obsession with him would overpower her interests in her own husband and young children. Especially after a trying sojourn with her mother and sisters in an Australian theosophical commune during her teenage years, the young Elisabeth's resentment of her mother's neglect eventually solidified into a lifelong suspicion towards any form of religious dogmatism, to which the opening citation of this article attests.

From the early 1920s, as a sixteen-year-old composition student in Paris, until her death in 1983, she produced over 300 works in a wide variety of genres, ranging in scale from the Sonata for Solo Viola, op. 5, to the full-length opera The Numbered (1967). ${ }^{3}$ Described by William Glock after her death as "a Catherine-wheel of intelligence," Lutyens was a determined, individualistic pioneer who, like Luigi Dallapiccola in Italy, began and persisted in writing serial music in a cultural environment which, in the early decades of her career, was generally hostile to the music of the Second Viennese School. ${ }^{4}$ The "mother of British serialism," as she was known by some (or, less kindly by others, "Twelve-tone Lizzie"), claimed that her adoption of serialist composition techniques arose not so much from any thorough knowledge of the music of Schoenberg, Webern, and Berg, but from her exposure in 1933 to the string fantasias of Purcell:

It was hearing these works, with their equality of part-writing, coupled with my satiety - to screaming point-with diatonic cadential harmony, that led me to discover gradually, for my own compositional needs, what some years later I heard described as "twelve-tone," "serial" composition. I had not, as yet, heard the names, still less the music, of the new Viennese School. ${ }^{5}$

In her doctoral dissertation, Sarah Tenant-Flowers considers the specific nature of Purcell's influence on Lutyens's works of the 1930s, noting a new contrapuntalism in the compositions that followed her discovery of his string fantasias. In these works, she sees as typically Purcellian the prevalent but

3 The only scholarly work devoted to a general assessment of Lutyens's music is the doctoral dissertation of Sarah Jane Tenant-Flowers, "A Study of Style and Techniques in the Music of Elisabeth Lutyens" (Ph.D. diss., University of Durham, 1991); however, it is unavailable outside the United Kingdom. For discussions of Lutyens's choral works, see Richard Alan Palmer, "The A Cappella Choral Works for Mixed Voices of Elisabeth Lutyens" (A.Mus.D. thesis, University of Illinois, 1984), and Catherine Roma, "The Choral Music of Twentieth-Century Composers Elisabeth Lutyens, Elizabeth Maconchy, and Thea Musgrave" (D.M.A. diss., University of Cincinnati, 1989). The most thorough and accessible article-length survey of Lutyens's compositional output is Anthony Payne's article "Lutyens, (Agnes) Elisabeth," in The New Grove Dictionary of Music and Musicians, ed. Stanley Sadie (London: Macmillan, 1980), 11:374-77. Other article-length surveys include Susan Bradshaw, "The Music of Elisabeth Lutyens," The Musical Times 112 (July 1971): 654-56; Bradshaw and Richard Rodney Bennett, "Elisabeth Lutyens's Stage Works," Tempo, no. 120 (March 1977): 47-48; and Robert Henderson, "Elisabeth Lutyens," The Musical Times 104 (August 1963): 551-55.

4 Sir William Glock, print script of BBC radio broadcast, "A Tribute to Elisabeth Lutyens," 15.12.83, 2155-2300. British Library Add.MS. 71114, fol. 220.

$5 A G B, 69$. 
"relaxed" use of pitch inversion, transposition, rhythmic augmentation, and diminution of short segments taken from a single, thematic melodic line:

Indeed, it is plain to see that her contrapuntal technique derives more from Purcell than from the Teutonic tradition as represented by Bach, and it signifies, with its denial of rigour and admittance of irregularity [i.e., rhythmic and intervallic variation], perhaps a typically English solution compared with that of Lutyens's Second Viennese counterparts. ${ }^{6}$

Still, Lutyens's insistence on her independent arrival at serialist principles in the late 1930s has engendered some controversy over the years. As she herself admitted in her autobiography, there would have been many opportunities for her to hear music of the Second Viennese School, either in live performance or in BBC radio broadcasts. ${ }^{7}$ But prior to 1934 she claimed to have heard only a performance of Schoenberg's Gurrelieder, which she "detested." In 1934 she heard the music of Webern for the first time in a performance by the Kolisch Quartet, and although she could not remember the name of the work they had played, she did recall her excitement at hearing what seemed to her "the most thrilling music since the great classics." At the 1938 ISCM Festival in London, Lutyens was profoundly affected for the second time by the music of Webern, at the premiere performance of his cantata Das Augenlicht, and from then on considered him "a guiding spirit of all future music." 10 Around this time, Lutyens composed her first piece based on a tone row, the Chamber Concerto no. 1, op. 8, for oboe, clarinet, bassoon, horn, trumpet, trombone and string trio, and she subsequently adopted serialism as a governing principle for most of her work.

For some, the greatest challenge to her claim of independence is the fact that in 1938 she met and later married the conductor and new music impresario Edward Clark (1888-1962), who had been a friend, student, and mentor of Arnold Schoenberg since 1910. Clark studied composition with Schoenberg in Berlin from 1911 to 1914, and also counted Webern and Berg among his friends, along with a host of other prominent composers. ${ }^{11}$ The question of influence with respect to Lutyens's independent arrival at serial principles is a difficult one, as it involves not only biographical and stylistic considerations, but also issues

6Tenant-Flowers, "A Study of Style and Techniques in the Music of Elisabeth Lutyens," 98.

7For an exhaustive account of live and broadcast performances of Second Viennese School repertoire in England during this period, see Jennifer Doctor, "The BBC and the Ultra-Modern Problem: A Documentary Study of the British Broadcasting Corporation's Dissemination of the Second Viennese School Repertory, 1922-36" (Ph.D. diss., Northwestern University, 1993), 583-651.

$8 A P S, 90$.

$9 A G B, 72$. She also recalled her initial puzzled reaction that it was "a strange piece by the composer of Der Freischütz."

$10 A G B, 76$.

11 The most reliable published accounts of Clark's early career are contained in APS, 75-86, and in Doctor, 676-98. Lutyens's own chapter in $A G B$ devoted to a biography of Clark unfortunately contains a number of factual errors. The British Library holds a large and fascinating collection of letters to Clark from almost all of the major figures in contemporary European music in the first half of the century, mostly composers but also conductors and performers. BL Add.MS. 52257. 
of gender bias, particularly in early critical assessments of Lutyens's achievements. In their biography of Lutyens, Meirion and Susie Harries deal with the question thoroughly and in a balanced manner, taking into account stylistic evidence from Lutyens's early compositions, as well as her personal life in the early $1930 \mathrm{~s} .12$

It was not until 1944 that Lutyens earned her first income from composition, when the composer William Walton commissioned her to write a work of her choice. The result of this commission was a dramatic scene entitled The Pit, a story of disaster in a mining community, which premiered at the Palermo ISCM Festival in 1947. Around this time she also began securing work as a film and radio composer, scoring British government propaganda films, industrial shorts, travelogues, radio plays and, later, Hammer horror films with titles like The Skull and The Earth Dies Screaming. She did not like being distracted from independent composition by this commercial work, but it was desperately necessary, since by the time she met Clark in 1938, his career as a conductor and program director with the $\mathrm{BBC}$ had already begun to disintegrate. In leaving her first husband to pursue her relationship with Clark, she had unwittingly catapulted herself into the situation of having to support not only herself, but also four young children and an almost continually unemployed second husband, throughout the difficult war years in Britain.

The postwar years were a marked improvement for Lutyens, however, as she received more commissions and performances. Two of these are counted among Lutyens's finest compositions: the highly successful 1946 cantata $\hat{O}$ saisons, $\hat{o}$ chateaux! for soprano, strings, harp, guitar, and mandolin, based on a poem by Arthur Rimbaud, and the lovely Motet (Excerpta Tractati LogicoPhilosophici), op. 27, based on excerpts from Wittgenstein's treatise clarifying and delimiting the role of language in the expression of thought. ${ }^{13}$ The Motet was commissioned by William Glock for the 1954 Dartington Summer School of Music, where it was premiered by the London Chamber Singers under the direction of Anthony Bernard. Glock's support of Lutyens's work did not end there: later, during his tenure as Music Controller for the BBC from 1959 to 1972 , Lutyens received nearly twice as many commissions from the BBC than any other composer, including Harrison Birtwhistle, Richard Rodney Bennett, Peter Maxwell Davies, Malcolm Williamson, Alan Rawsthorne, and Malcolm Arnold.

12APS, 90-94. Lutyens's first marriage, to singer Ian Glennie, took place in 1933, and by 1936 she had given birth to three children, including a set of twins-circumstances which would indeed have resulted in a certain degree of social and professional isolation. Her fourth child, Clark's son, was born in 1941 , a year before her divorce from Glennie and remarriage to Clark.

13Elisabeth Lutyens, $\hat{O}$ saisons, $\hat{O}$ chateaux! Cantata for Soprano and Strings, op. 13 (London: Mills Music, 1960). This piece is commercially recorded on a 1960s vinyl LP entitled Schoenberg and Britten, performed by the soprano Marilyn Tyler with the Royal Philharmonic Orchestra conducted by Norman Del Mar (EMI ASD 612). The Motet (Excerpta Tractati Logico-Philosophici) for unaccompanied chorus SATB (London: Schott, 1965) is recorded on a 1966 vinyl LP by the John Alldis Singers entitled Lutyens, Gardner, Joubert and Naylor (Argo ZRG 5426). 
Following the unexpected death of Edward Clark in 1962, Lutyens's compositional output temporarily slowed, but by the end of 1967 she had resumed her earlier rate of composition and had completed her magnum opus, the opera The Numbered. ${ }^{14}$ Around this time, Lutyens began to develop a profile in the United States, and was invited by the composer-and friend-Virgil Thomson to New York and Pittsburgh to participate in a composers' forum. During this American adventure, she also attended performances of her works and was entertained at a New York party in her honour whose other guests included Truman Capote, Norman Mailer, and Edward Albee, as well as Isaac Stern and Leonard Bernstein.

In 1969, nominated by a number of eminent British musicians including Richard Rodney Bennett, Adrian Boult, Arthur Bliss, and Michael Tippett, Lutyens was made a Commander of the British Empire by Queen Elizabeth II in honour of her contribution to contemporary music in England. Ten years later, she was again recognized in North America, with a lifetime accomplishment award from the American Academy and Institute of Arts and Letters. Her seventy-fifth birthday in 1981 received considerable attention from the British print and broadcast media. By this time she was suffering from severe arthritis and as a consequence her compositions were becoming progressively shorter and more infrequent. She died suddenly of heart failure at her London home on 13 April 1983, at the age of seventy-six.

\section{TEXT IN THE MUSIC OF ELISABETH LUTYENS}

Much of Lutyens's music was composed in association with text of some sort, not only in the traditional musical genres of song and opera, but also in her commercial work composing for film, radio, and theatre. In her vocal music, she garnered a reputation for setting a remarkable variety of texts, from John Donne and Sir Thomas Browne to James Joyce and Stevie Smith, from Inuit poetry to the "I" section of the Oxford Book of English Verse's Index of First Lines (in a song for baritone and piano mischievously entitled "The Egocentric").

This range in texts is exemplified in the pair of works mentioned earlier, the Rimbaud cantata $\hat{O}$ saisons, $\hat{o}$ chateaux! and the Wittgenstein Motet. Certainly, there is little to compare between the Motet's scholarly German prose text and the cantata's ecstatic French symbolist poetry. What they do have in common, however, is the fact that in both cases the search for a text began only after the music had begun to develop in Lutyens's imagination. Only when she was satisfied that a text appropriately embodied or expressed in verbal form the music that was already taking shape, did she bring words and music together. Of the early stages of the cantata's composition, for example, Lutyens wrote:

14The Numbered, based on a play by the 1981 Nobel Prize winner Elias Canetti, is as yet unpublished and unperformed. A study of the opera is the subject of the present author's Ph.D. dissertation (in progress). 
I had conceived the piece, even heard the complete sound-in form and timbre-and begun the writing whilst still searching for the right words. I was hearing a soprano voice, of the calibre of Oda Slobodskaya's, in a soaring lyrical lament, supported by all variety of string sounds-like an enlarged, amplified guitar. ${ }^{15}$

One day over drinks in a London pub, she described these musical images and her search for a matching text to a friend, who responded by suggesting the Rimbaud poem which she eventually chose.

A few years later, again at a pub but in different company, she had a similar conversation regarding her search for a text for the choral piece she had been commissioned to write, and once again, the suggestion of author and work came from someone else. She remarked to the $\mathrm{BBC}$ producer and poet Terence Tiller and her husband Edward Clark on this occasion that, in trying to find a suitable text for the music that was beginning to take shape, she was looking for "something accurate and impersonal but not religious." 16 Tiller and Clark both suggested Wittgenstein, and she goes on to describe her reaction upon first opening a copy of the Tractatus: "From the first glance I knew I had found what I wanted, the words and ideas being ideally suited to the already formulated sound and architecture of the music in my mind." 17 There is no documentary evidence among Lutyens's papers indicating the specific degree of completion that the Motet's musical structure had reached by the time the text was chosen. But anecdotal accounts of the process by which text and music were brought together suggest that Lutyens's compositional decisions may have been influenced by the text to some degree.

Although Lutyens opted to set the text in the original German, she needed to translate it into English for her own comprehension, and for this task she enlisted the help of Clark, Tiller, and the composer Shula Doniach. Doniach reported to Meirion and Susie Harries that she had written down the original German for Lutyens "in musical notation, giving each syllable its correct quantity, and rehearsed [Lutyens] in them until she knew the meaning of every sound." 18 According to Doniach, Lutyens was constantly working on the music, which was "virtually complete" by the time she brought text and music together. Lutyens herself wrote:

The music was now developing too quickly in my mind to delay further, so I decided that for the next fortnight I would have to become German - think in German. In a couple of days I had every sound, caesura and meaning of the words by heart and in due course music and words were married, the engagement having been a long one. ${ }^{19}$

$15 A G B, 168$.

16Ibid., 222-23.

17 Ibid.

18APS, 155-56.

$19 A G B, 223$. 
These accounts confirm that the text was not simply grafted onto a fully formed musical structure. Rather, the development of the Motet's musical structure proceeded in parallel with the development of Lutyens's comprehension of the text, and it is reasonable to surmise that, during this stage, the composer's understanding of the text exercised some influence over the emerging musical structure.

On the basis of these accounts of the Motet's composition by Doniach and Lutyens, the process by which words and music were brought together can be divided into three phases. The first of these consists of Lutyens's preliminary formulations of the Motet's musical structure, and her search for a text that would fittingly represent the "sound and architecture" she had in mind. During this phase, which ends with the choice of the Wittgenstein text, the music can be said to have been both conceptually and temporally prior to the text. In the second phase (to use Lutyens's analogy, the "engagement"), the musical structure and Lutyens's understanding of the text developed concurrently, and are likely to have exercised some reciprocal influence. The third phase (the "wedding") finalized the specific, note-to-syllable linking of music and words as they are associated in the completed Motet.

Much analysis of vocal music rests on the premise that much of the musical structure of a given work is determined by the composer's understanding of its text. Analyses of this sort frequently seek to demonstrate the ways in which a given piece of vocal music "expresses" or "represents" its text, and tacitly assume that the music is in this way subsidiary to the text. A convincing interpretation of the Wittgenstein Motet could certainly be made according to this analytical paradigm. But what I wish to explore further here is the idea, inherent in the first of the three compositional phases outlined above, that in certain cases it is possible to conceive of a given text as an image or representation of ideas that are essentially musical in nature, in other words, of text as representation of music.

To this end, the analysis which follows will examine in detail the relations between music and words in certain passages of the Wittgenstein Motet. The first part of this discussion will focus on the text of the Tractatus itself and the methods by which Lutyens adapted it to her compositional needs. The next, and lengthiest, portion of the discussion, will be devoted to a pitch-class structural analysis of three passages of particular textual and musical import.

\section{THE ADAPTATION OF THE TEXT}

The Tractatus logico-philosophicus consists of a numbered series of 526 propositions varying in length from one sentence to several paragraphs, many including diagrams, charts, or formulas. Consequently, in order to serve as the text for a single-movement choral piece, the treatise needed to be drastically reduced. Lutyens culled 30 propositions from the original, and from these constructed the final text of the Motet, which is presented in Example 1a, along with the relevant proposition numbers. Example 1b provides the English translation that appears on the inside cover of the published score. 


\begin{tabular}{|c|c|}
\hline 1 & Die Welt ist alles, was der Fall ist. \\
\hline 1.1 & Die Welt ist die Gesamtheit der Tatsachen. ... \\
\hline 1.13 & Die Tatsachen im logischen Raum sind die Welt. \\
\hline 2 & Was der Fall ist, die Tatsache, ist das Bestehen von Sachverhalten. \\
\hline 2.01 & Der Sachverhalt ist eine Verbindung von Gegenständen. ... \\
\hline 2.021 & Die Gegenstände bilden die Substanz der Welt. ... \\
\hline 2.0251 & Raum, Zeit und Farbe ... sind Formen der Gegenstände. \\
\hline 2.03 & $\begin{array}{l}\text { Im Sachverhalt hängen die Gegenstände ineinander, wie die Glieder einer } \\
\text { Kette. }\end{array}$ \\
\hline 2.04 & Die Gesamtheit der bestehenden Sachverhalte ist die Welt. \\
\hline 2.06 & $\begin{array}{l}\text { Das Bestehen und Nichtbestehen von Sachverhalten ist die Wirklichkeit, } \\
\text { ist die Welt. ... }\end{array}$ \\
\hline 2.12 & Das Bild ist ein Modell der Wirklichkeit, ein Bild der Welt. \\
\hline 3 & Das logische Bild der Tatsachen ist der Gedanke. \\
\hline 4 & Der Gedanke ist der sinnvolle Satz. \\
\hline 4.01 & Der Satz ist ein Bild der Wirklichkeit. ... \\
\hline *3.1411 & ... Der Satz ist artikuliert. \\
\hline 4.022 & $\begin{array}{l}\text { Der Satz zeigt seinen Sinn. Der Satz zeigt, wie es sich verhält, wenn er } \\
\text { wahr ist. Und er sagt, daß es sich so erhält. }\end{array}$ \\
\hline 4.024 & Einen Satz verstehen, heißt, wissen was der Fall ist, wenn er wahr ist. ... \\
\hline 4.121 & ... Der Satz zeigt die logische Form der Wirklichkeit. Er weist sie auf. \\
\hline 5.552 & ... Die Logik ist vor jeder Erfahrung-daß etwas so ist. ... \\
\hline 5.61 & Die Logik erfüllt der Welt. ... \\
\hline 5.621 & Die Welt und das Leben sind Eins. \\
\hline 5.63 & Ich bin meine Welt. ... \\
\hline 6.41 & $\begin{array}{l}\text { Der Sinn der Welt muß außerhalb ihrer liegen. In der Welt ist alles, wie } \\
\text { es ist, und geschieht alles, wie es geschieht. ... }\end{array}$ \\
\hline 6.431 & Wie auch beim Tod die Welt sich nicht ändert, sondern aufhört. \\
\hline 6.4311 & $\begin{array}{l}\text { Der Tod ist kein Ereignis des Lebens. Den Tod erlebt man nicht. ... (Der) } \\
\text { lebt ewig, der in der Gegenwart lebt. }\end{array}$ \\
\hline 6.4312 & $\begin{array}{l}\text {... Ist denn dieses ewige Leben dann nicht ebenso rätselhaft wie das } \\
\text { gegenwärtige? Die Lösung des Rätsels des Lebens in Raum und Zeit liegt } \\
\text { außerhalb von Raum und Zeit. ... }\end{array}$ \\
\hline *6.512 & $\begin{array}{l}\text { Die Lösung des Problems des Lebens merkt man am Verschwinden dieses } \\
\text { Problems. ... }\end{array}$ \\
\hline 6.5 & $\begin{array}{l}\text { Das Rätsel gibt es nicht.Wenn sich eine Frage überhaupt stellen läßt, so } \\
\text { kann sie auch beantwortet werden. }\end{array}$ \\
\hline 6.51 & $\begin{array}{l}\text {... Denn Zweifel kann nur bestehen, wo eine Frage besteht; eine Frage nur, } \\
\text { wo eine Antwort besteht; und diese nur, wo etwas gesagt werden kann. }\end{array}$ \\
\hline 7 & Wovon man nicht sprechen kann, darüber muß man schweigen. \\
\hline
\end{tabular}

Example 1a: Text of the Motet ${ }^{20}$

20Ludwig Wittgenstein, Tractatus logico-philosophicus (1921), in Werkausgabe (Frankfurt: Suhrkamp, 1989), 1:7-85. Emphasis in original. In proposition 2.12, the phrase "ein Bild der Welt" is Lutyens's addition. 


\begin{tabular}{|c|c|}
\hline 1 & The world is all that is the case. \\
\hline 1.1 & The world is the totality of facts. ... \\
\hline 1.13 & Facts in logical space are the world. \\
\hline 2 & What is the case, the fact, is the existence of atomic facts. \\
\hline 2.01 & An atomic fact is a combination of objects. ... \\
\hline 2.021 & Objects form the substance of the world. ... \\
\hline 2.0251 & Space, time and colour are forms of objects. \\
\hline 2.03 & In the atomic facts objects hang one in another, like the links of a chain. \\
\hline 2.04 & The totality of existent atomic facts is the world. \\
\hline 2.06 & $\begin{array}{l}\text { The existence and non-existence of atomic facts is the reality, is the world. } \\
\ldots\end{array}$ \\
\hline 2.12 & The picture is a model of reality (a picture of the world). \\
\hline 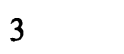 & The logical picture of facts is thought. \\
\hline 4 & The thought is the significant proposition. \\
\hline 4.01 & The proposition is a picture of reality. ... \\
\hline *3.1411 & ...The proposition is articulate. \\
\hline 4.022 & $\begin{array}{l}\text { The proposition shows its sense. The proposition shows how things stand, } \\
\text { if it is true. And it says, that they do so stand. }\end{array}$ \\
\hline 4.024 & $\begin{array}{l}\text { To understand a proposition means to know what is the case, if it is true. } \\
\ldots\end{array}$ \\
\hline 4.121 & ... The proposition shows the logical form of reality. It exhibits it. \\
\hline 5.552 & ... Logic precedes every experience-that something is so. ... \\
\hline 5.61 & Logic fills the world. ... \\
\hline 5.621 & The world and life are one. \\
\hline 5.63 & I am my world. ... \\
\hline 6.41 & $\begin{array}{l}\text { butside the world. In the world everything } \\
\text { happen.... }\end{array}$ \\
\hline 6.431 & As in death, too, the world does not change, but ceases. \\
\hline 6.4311 & $\begin{array}{l}\text { Death is not an event of life. Death is not lived through. ... (He) lives } \\
\text { eternally who lives in the present. }\end{array}$ \\
\hline 6.4312 & $\begin{array}{l}\text {... Is this eternal life, then, not as enigmatic as our present one? The solution } \\
\text { of the riddle of life in space and time lies outside space and time. ... }\end{array}$ \\
\hline *6.512 & The solution of the problem of life is seen in the vanishing of this problem.... \\
\hline 6.5 & $\begin{array}{l}\text { The riddle does not exist. If a question can be put at all, then it can also } \\
\text { be answered. }\end{array}$ \\
\hline 6.51 & $\begin{array}{l}\text {... For doubt can only exist where there is a question; a question only } \\
\text { where there is an answer; and this only where something can be said. }\end{array}$ \\
\hline 7 & Whereof one cannot speak, thereof one must remain silent. \\
\hline
\end{tabular}

Example 1b: English translation of the text ${ }^{21}$

21 English translation by David F. Pears and Brian F. McGuinness, taken from the score of the Motet (London: Schott, 1965). 
Given that so much of the detailed logical structure of the original Tractatus has been excised, the thread of continuity that remains depends as much on verbal repetitions and echoes as it does on step-by-step logical progression. The first three sentences provide an apt example: "Die Welt ist alles, was der Fall ist. Die Welt ist die Gesamtheit der Tatsachen. Die Tatsachen im logischen Raum sind die Welt." The first two lines begin with the common phrase "Die Welt"; the second adds the term "Tatsachen"; the third also contains both, but "in retrograde," and also introduces the words "logischen" and "Raum," foreshadowing important recurrences of these terms later in the text. This surface connectivity evokes the aura, but not the structure, of logical thought.

Lutyens's own modifications to the text, although slight, further suggest the importance of this verbal connectivity over strict adherence to logical progression. First, the numbering of the propositions shows that, although in general she followed the original ordering of the Tractatus, there are two exceptions (indicated in Examples 1a and $1 \mathrm{~b}$ by asterisks): propositions 3.1411 ("Der Satz ist artikuliert") and 6.512 ("Die Lösung des Problems des Lebens merkt man am Verschwinden dieses Problems") occur either after or before their normal place in the numerical sequence. ${ }^{22}$ In both cases, the re-ordering results in the repetition of the beginning of the preceding sentence, in a kind of textual imitation.

Second, although almost all of the other modifications of the text involve elision, not only between but within propositions (as indicated in Examples 1a and $1 \mathrm{~b}$ by ellipses), in one instance Lutyens added to the text. In the original Tractatus, proposition 2.12 reads "Das Bild ist ein Modell der Wirklichkeit," but in the Motet, the sentence continues with the phrase "ein Bild der Welt," presumably an attempt on Lutyens's part to create an end-rhyme with the two preceding propositions.

The verbal connectivity linking one statement to the next makes it somewhat difficult to divide the text into discrete sections, especially as one encounters the text in the score of the Motet and in performance without the benefit of Wittgenstein's numerical labels. Nevertheless, it is possible to discern three major areas of discussion. The first of these (propositions 1-2.12, "Die Welt ist alles, ... ist die Wirklichkeit, ist die Welt"), posits the world as the "totality of facts," of which Wittgenstein notes two kinds: "Tatsachen" ("deed-things") and "Sachverhalten" ("states of things"). The second (propositions 3-5.61, "Das logische Bild ... Die Logik erfüllt der Welt") concentrates on the importance of the logical proposition ("Satz") as a model of the world, and reflects on the crucial role of language and logic in the experience, demonstration, and construction of reality. But there is a striking shift of emphasis in the third section of the text, extending from proposition 5.621

22 Wittgenstein explained his numbering system as follows: "The decimal numbers assigned to the individual propositions indicate the logical importance of the propositions, the stress laid on them in my exposition. The propositions $n .1, n .2, n .3$, etc. are comments on proposition no. $n$; the propositions $n . m 1$, $n . m 2$, etc. are comments on proposition no. n.m; and so on." Wittgenstein, Tractatus logicophilosophicus, trans. David F. Pears and Brian F. McGuinness (London: Routledge and Kegan Paul, 1974), 5. 
("Die Welt und das Leben sind Eins") until the end. Prior to this point, the concerns of the text have remained highly abstract, but this final discussion addresses the more personal and immediate problems of human life and death, contending that "Die Lösung des Problems des Lebens merkt man am Verschwinden dieses Problems" "the solution of the problem of life is seen in the vanishing of this problem"). The final statement of the Motet's text is Wittgenstein's main proposition 7, which brings the Tractatus to a close without further elaboration: "Wovon man nicht sprechen kann, darüber muss man schweigen" ("Whereof one cannot speak, thereof one must be silent").

The significant contrast between the abstractness of the first two sections and the directly human concerns of the third casts the text into a kind of asymmetrical bipartite form. The musical form of the Motet can be seen in similar terms: the first two-thirds of the 151-bar piece are assigned to the full chorus, but at the end of bar 95 , coincident with the shift in the text towards the human problems of life and death, there is an abrupt change of texture with the onset of a rhapsodic 13-bar solo for a lone soprano voice. Following a return in bars 110-31 to the full choral texture, there is a second passage of solos for individual tenor, bass, alto, and soprano voices, which extends until the resumption in bar 147 of the full choral texture (though at the subdued dynamic level of $p p p$ ) for the final proposition of the Motet.

\section{THE SERIAL LANGUAGE OF THE MOTET}

The Motet is serial in many regards, but it is based less on a twelve-tone row than on pairs of complementary hexachords and certain internal re-orderings of these hexachords. Analysis of the first two phrases, reproduced in Example 2 , demonstrates both this strongly hexachordal orientation and the difficulty of defining a single twelve-tone row for the Motet.

The first phrase (bars 1-3) begins with a statement in the alto of the hexachord $<\mathrm{D}, \mathrm{D} b, \mathrm{~F}, \mathrm{~A}, \mathrm{~B} b, \mathrm{G} b>.^{23}$ This hexachord, the unordered form of which I will call $\mathrm{H}$, is a member of the set class $[0,1,4,5,8,9]$, or 6-20 in Forte's typology. The tenor enters at the end of bar 1, singing against the alto's hexachord $\mathrm{H}$ its $\mathrm{T}_{10}$ transposition $<\mathrm{C}, \mathrm{B}, \mathrm{E} b, \mathrm{G}, \mathrm{A} b, \mathrm{E}>$; the unordered form of this hexachord I will call h. Since $T_{10}$ (along with $T_{2}$ and $T_{6}$ ) maps any 6-20 hexachord onto its complement, the alto and tenor parts in these three bars complete the aggregate. The second phrase (bars 3-6) likewise presents an aggregate formed from $\mathrm{H}$ and $\mathrm{h}$, this time sung in the bass and soprano, respectively, and once again, the operation $\mathrm{T}_{10}$ maps the order positions of the first hexachord onto those of the second.

Note, however, that although the order of the hexachords in each phrase is consistent, the order of the pitch classes within each hexachord is different. Specifically, in the second phrase each hexachord is re-ordered such that its constituent trichords are retrograded internally: that is, $\angle \mathrm{D}, \mathrm{D} b, \mathrm{~F}+\mathrm{A}, \mathrm{B} b, \mathrm{G} b\rangle$ in the first, alto statement of $\mathrm{H}$ becomes $<\mathrm{F}, \mathrm{D} b, \mathrm{D}+\mathrm{F} \sharp, \mathrm{B} b, \mathrm{~A}>$ in the second, bass statement;

23 In this article, square brackets ([ ]) indicate set classes, angle brackets ( $<>)$ denote ordered sets, and curly brackets $(\{\mid)$ unordered sets. 
To Wilkem Glock

Motet

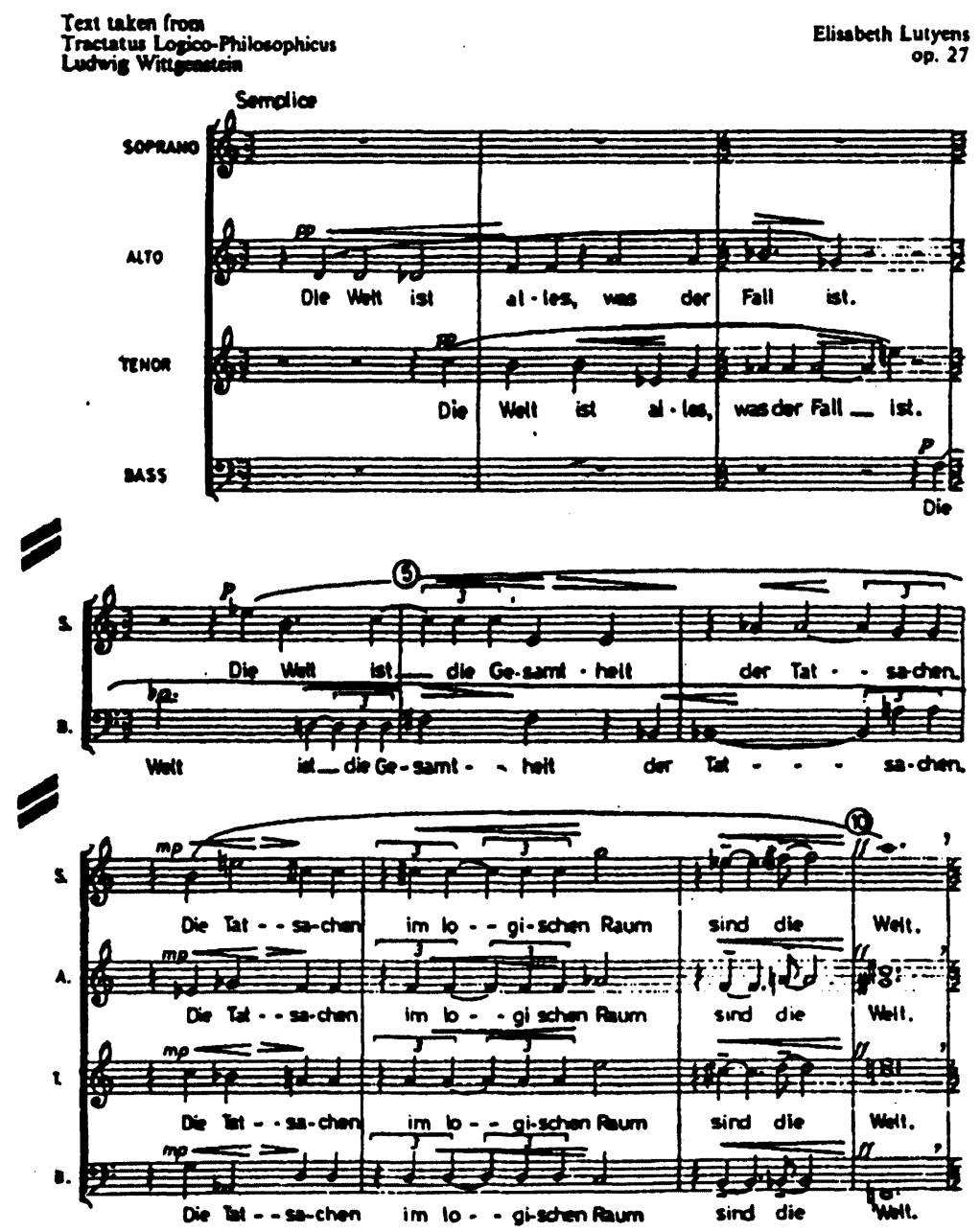

Example 2: Elisabeth Lutyens, Motet, op. 27: subsection 1, bars 1-10. All musical examples copyright Schott \& Co. Ltd (London). Reproduced by permission.

likewise, $<\mathrm{C}, \mathrm{B}, \mathrm{E} b+\mathrm{G}, \mathrm{A} b, \mathrm{E}>$ in the tenor becomes $<\mathrm{E} b, \mathrm{~B}, \mathrm{C}+\mathrm{E}, \mathrm{A} b, \mathrm{G}>$ in the soprano.

On the basis of the slightly later onset of $h$ in both phrases, we can perhaps consider the ordered pair of hexachords $<\mathrm{H}, \mathrm{h}\rangle$ a possible template for the basic row of the Motet. If each $\langle\mathrm{H}, \mathrm{h}\rangle$ aggregate is arranged as a consecutive series of twelve pitch classes- $<\mathrm{D}, \mathrm{D} b, \mathrm{~F}, \mathrm{~A}, \mathrm{~B} b, \mathrm{G} b+\mathrm{C}, \mathrm{B}, \mathrm{E} b, \mathrm{G}, \mathrm{A} b, \mathrm{E}>$ in bars $1-3$ and $<F, D b, D, F \#, B b, A+E b, B, C, E, A b, G>$ in bars 3-6-the first series maps 
onto the second under $\mathrm{RI}_{9}$, suggesting that the alto-tenor series in the first three bars may indeed function as a basic row. 24

Still, because the statements of the hexachords overlap within each phrase, there are other possible ways of ordering the twelve pitch classes of each aggregate: for example, if the pitch classes of the first phrase are arranged according to the order in which they are actually heard, the first ordered trichord of the series is not $\langle\mathrm{D}, \mathrm{D} b, \mathrm{~F}\rangle$, but $\langle\mathrm{D}, \mathrm{D} b, \mathrm{C}\rangle$. The simultaneity on the downbeat of bar 2 introduces two possibilities for continuation, either $\langle F, B\rangle$ or $\langle\mathrm{B}, \mathrm{F}\rangle$; similarly, all subsequent simultaneities could be interpreted in either of two ways. Thus, the alto-tenor $\langle\mathrm{H}, \mathrm{h}\rangle$ series in bars $1-3$ represents only one of several possible orderings of the twelve pitch classes in bars 1-6, and a referential series cannot yet be determined.

In the preceding discussion, the four hexachords in bars 1-6 were grouped into complementary pairs such that the first aggregate was formed by the alto and tenor in bars 1-3, and the second by the bass and soprano in bars 3-6. In other words, concurrent hexachords yielded consecutive aggregates. As Figure 1 demonstrates, however, it is also possible to group the hexachords into consecutive complementary pairs on the basis of register, such that one aggregate is formed by the female voices (the alto-soprano $<\mathrm{H}, \mathrm{h}>$ pair $<\mathrm{D}, \mathrm{D} b, \mathrm{~F}, \mathrm{~A}, \mathrm{~B} b, \mathrm{G} b+\mathrm{E} b, \mathrm{~B}, \mathrm{C}, \mathrm{E}, \mathrm{A} b, \mathrm{G}>$ ), and another by the male (the tenor-bass $<\mathrm{h}, \mathrm{H}>$ pair $<\mathrm{C}, \mathrm{B}, \mathrm{E} b, \mathrm{G}, \mathrm{A}, \mathrm{E} b+\mathrm{F}, \mathrm{D} b, \mathrm{D}, \mathrm{F} \sharp, \mathrm{B} b, \mathrm{~A}>$ ). These two strata unfold concurrently over the first six bars of the Motet, instantiating something like the standard, Schoenbergian hexachordal combinatoriality, except that there is no single serial operation that can map the corresponding order positions of the two complete series onto each other: the first hexachord in the alto-soprano series maps onto its counterpart in the tenor under $T_{10}$, but the second maps onto its counterpart in the bass under $T_{2}$. Furthermore, as Figure 1 illustrates, the bass enters prior to the soprano, and thus it is more consistent with the musical surface to hear the soprano as the

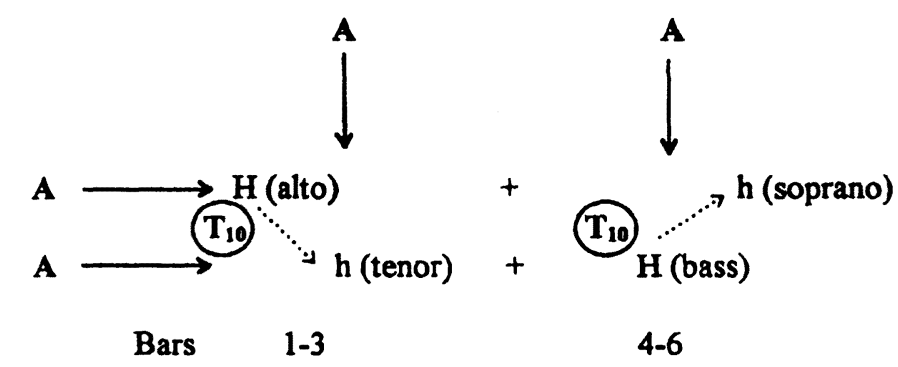

Figure 1: Hexachordal organization, bars 1-6

24 In this article, inversion indices indicate the sum of the inversionally-paired pitch class numbers, where $C=0$. For example, under $I_{9}$, pcs $0(C)$ and 9 (A) map onto each other, as do pcs 1 and 8 (C\# and $G \sharp), 2$ and 7 (D and $G), 3$ and 6 (Eb and $F \sharp)$, and 4 and 5 (E and $F$ ). 
$\mathrm{T}_{10}$ transposition of the bass, supporting the original model of two consecutive $<H, h>$ aggregates in which the first hexachord maps onto the second under $\mathrm{T}_{10}$.

The pitch-class structure of the Motet's first six bars, then, while it presents no less than four possible partitionings of the aggregate, does not establish any particular ordering of the twelve pitch classes as referential. But the consistent partitioning of these four aggregates into $\{\mathrm{H}, \mathrm{h}\}$ pairs clearly establishes the status of the 6-20 hexachord. In particular, the ordered hexachord $\langle\mathrm{H}\rangle=$ $<\mathrm{D}, \mathrm{D} b, \mathrm{~F}, \mathrm{~A}, \mathrm{~B} b, \mathrm{G} b>$ seems to have special significance, since as the first completed hexachord of the Motet, it begins two of the four aggregate partitionings; it seems likely, therefore, that this hexachord forms the first half of the Motet's basic row. At this point in the Motet, however, the second half is still indefinable, since the complement of $\langle\mathrm{H}>$ has yet to be heard in a consistent ordering.

Towards the establishment of a consistent ordering of the second half of the row, I will examine two other passages of particular formal significance in the Motet which begin with a statement of $\langle\mathrm{H}\rangle$. The first of these is the beginning of the monophonic soprano solo, bars 95-100, reproduced as Example 3. The first five pitch classes of this solo, $\langle\mathrm{D}, \mathrm{C} \sharp, \mathrm{F}, \mathrm{A}, \mathrm{B} b\rangle$, reprise the opening alto hexachord, with the exception of the pitch class $G b$, which would be expected to follow the $\mathrm{B} b 5$ in bar $97 .{ }^{25}$ But although the solo begins with $\langle\mathrm{H}\rangle$, its second hexachord $<\mathrm{E}, \mathrm{A} b, \mathrm{G}, \mathrm{E} b, \mathrm{~B}, \mathrm{C}>$ (bars 97-100) presents yet another ordering of $h$, and thus we still do not have a consistent ordering of the twelve pitch classes from which to discern a single basic row.

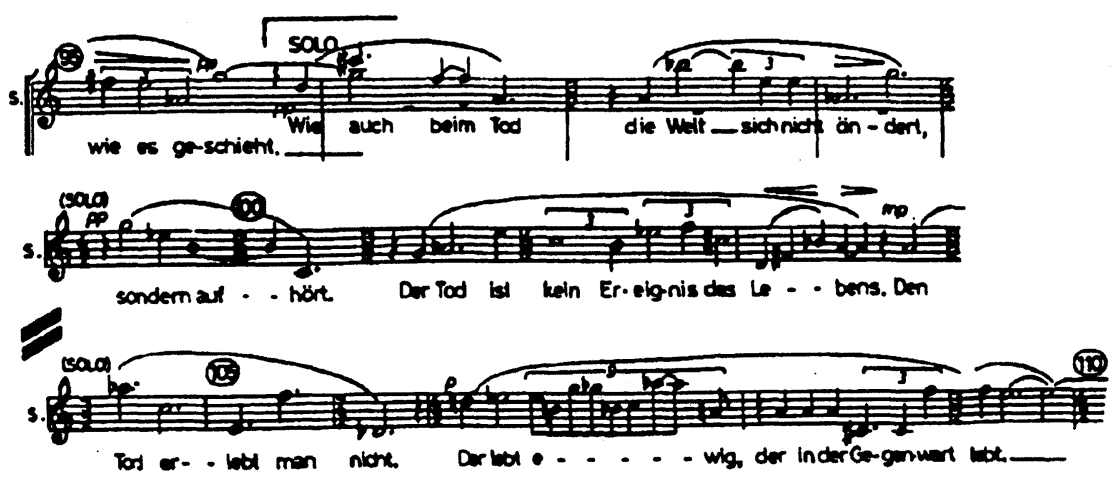

Example 3: Soprano solo, bars 95-109

25 Given the repetition of E5 in bar 96 and Lutyens's otherwise rigorous treatment of pitch-class organization throughout the Motet, it seems likely that the missing $G b$ is a typographical error (not unusual in published scores of Lutyens's works). Therefore, further discussions of this passage will assume that the word sich in bar 96 should be sung to the pitch $\mathrm{Gb5}$, and consequently that the first ordered hexachord of the soprano solo is equivalent to $\mathrm{H}$. 


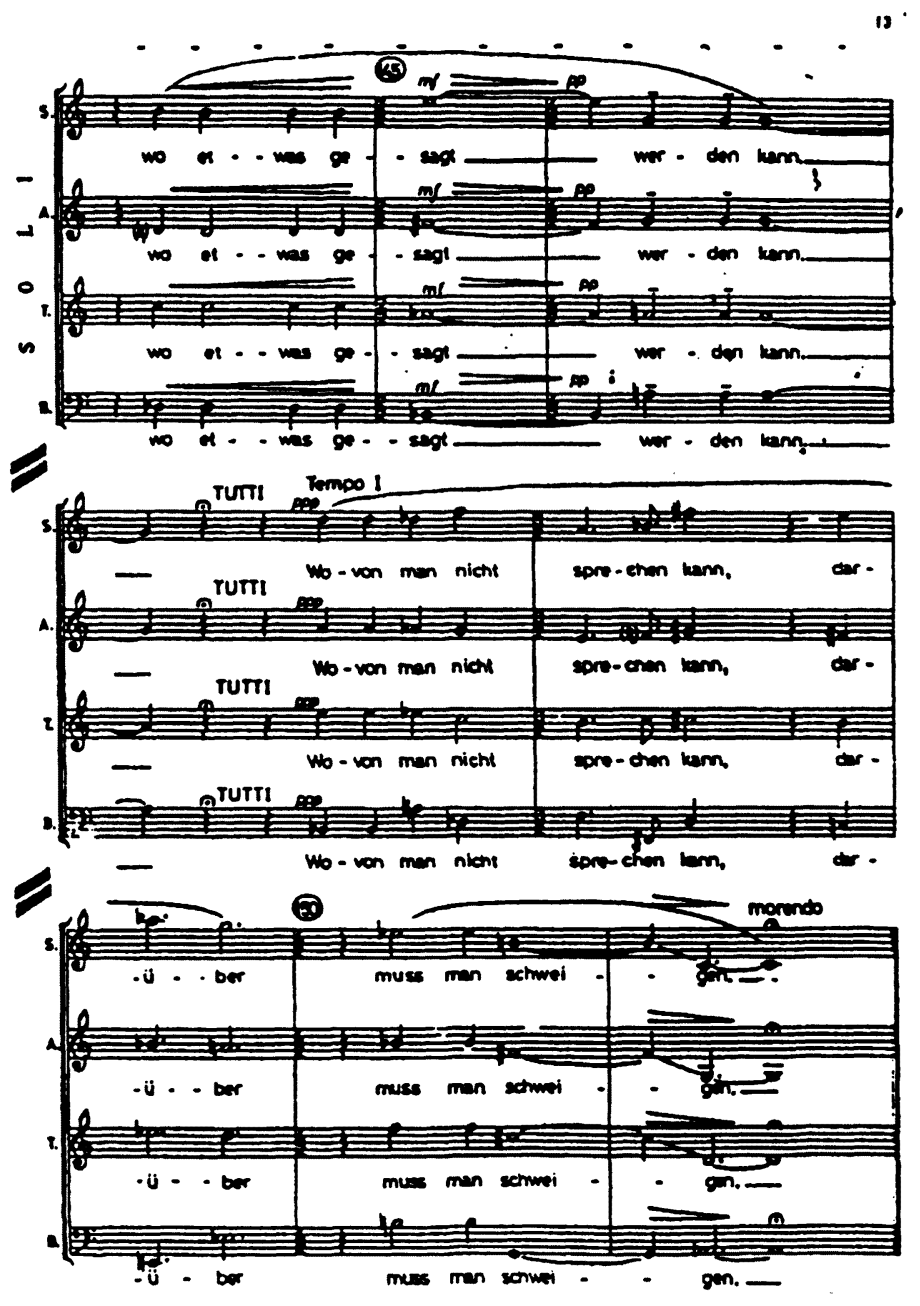

Example 4: Closing phrase, bars 147-51

Examination of the second hexachord in the soprano part of the Motet's final phrase, reproduced as Example 4, suggests a solution to the problem of the row's identity. This phrase begins with $\langle\mathrm{H}\rangle$ in the soprano in bars $147-48$, and continues on with the unfolding of the aggregate by answering the first hexachord with $h$ in an ordering we have heard before, namely, $<E, A b, G, E b, B, C>$, the second hexachord of the soprano solo in bars 97-100.

In part because of the formal significance of the repetition of this particular ordering in the Motet's closing moments, I will define the basic row of the Motet as $\mathrm{P}=\langle\mathrm{D}, \mathrm{C} \sharp, \mathrm{F}, \mathrm{A}, \mathrm{B} b, \mathrm{G} b, \mathrm{E}, \mathrm{A} b, \mathrm{G}, \mathrm{E} b, \mathrm{~B}, \mathrm{C}\rangle$. Another convincing feature of this ordering, however, is the symmetrical interval-class sequence $<1,4,4,1,4,2,4,1,4,4,1>$ by which it proceeds: Lutyens was particularly fond of palindrome (both musical and verbal), and, as the following analysis will illustrate, frequently used it as a structuring device in her compositions. 
Figure 2 provides a row chart showing the transpositions and inversions of $P$. The special properties of the 6-20 hexachord from which $\mathrm{P}$ is constructed manifest themselves in the row chart in certain ways. Because of the intervallic structure of this hexachord type, there are only two distinct transpositions of 6-20 other than $\mathrm{H}$ and $\mathrm{h}:\{\mathrm{D}, \mathrm{E} b, \mathrm{~F} \sharp, \mathrm{G}, \mathrm{B} b, \mathrm{~B}\}$ and $\{\mathrm{C}, \mathrm{C} \#, \mathrm{E}, \mathrm{F}, \mathrm{A} b, \mathrm{~A}\}$, which $\mathrm{I}$ shall call $\mathrm{H} 1$ and $\mathrm{h} 1$, respectively. Since this pair of hexachords $\{\mathrm{H} 1, \mathrm{~h} 1\}$ also forms the aggregate, the forty-eight forms of $P$ fall into one of two categories, the first, which I shall call $\mathrm{A}$, defined by its $\{\mathrm{H}, \mathrm{h}\}$ partitioning of the aggregate, and the second, $\mathrm{Al}$, by its $\{\mathrm{H} 1, \mathrm{~h} 1\}$ partitioning. The row chart shows that category $A$ contains $T_{0} P$, its even-numbered transpositions and odd-numbered inversions, while $\mathrm{A} 1$ contains the remaining twenty-four row forms, that is, the odd-numbered transpositions and even-numbered inversions of $P$.

\begin{tabular}{|c|c|c|c|c|c|c|c|c|c|c|c|c|}
\hline & $\mathbf{I}, \mathbf{P}$ & $I_{\mathbf{B}} \mathbf{P}$ & $\mathbf{I}, \mathbf{P}$ & $I_{11} \mathbf{P}$ & $\mathbf{I}_{0} \mathbf{P}$ & $\mathbf{I}_{\mathbf{P}} \mathbf{P}$ & $\mathbf{I}_{\mathbf{b}} \mathbf{P}$ & $I_{10} P$ & $\mathbf{I , P}$ & $\mathbf{I}, \mathbf{P}$ & $\mathbf{I}_{1} \mathbf{P}$ & $\mathbf{I}_{2} \mathbf{P}$ \\
\hline$T_{0} P$ & D & $\mathrm{Db}$ & $\mathbf{F}$ & A & $\mathrm{Bb}$ & $\mathbf{G}_{b}$ & $\mathbf{E}$ & $\mathrm{Ab}$ & $\mathbf{G}$ & $E_{b}$ & B & C \\
\hline$T_{1} P$ & Eb & D & $F$ & Bb & B & G & $\mathbf{F}$ & A & $\mathrm{Ab}$ & E & C & $\mathrm{C \#}$ \\
\hline$T, P$ & B & Bb & D & $F_{H}$ & G & $\mathrm{Eb}$ & $\mathrm{C}$ & $\mathbf{F}$ & E & C & Ab & A \\
\hline $\mathbf{T}, \mathbf{P}$ & G & $G_{b}$ & $\mathrm{Bb}$ & D & Eb & B & A & Cl & C & $A b$ & E & $\mathbf{F}$ \\
\hline$T_{4} \mathbf{P}$ & F & $\mathbf{F}$ & A & $C$ & D & $\mathrm{Bb}$ & $A b$ & C & B & G & Eb & E \\
\hline$T_{0} P$ & Bb & A & $C \forall$ & $\mathbf{F}$ & $F$ & D & c & $E$ & $\mathrm{E}_{6}$ & B & G & Ab \\
\hline$T_{10} P$ & c & B & $\mathrm{E}_{b}$ & G & $\mathrm{Ab}$ & $\mathbf{E}$ & D & F & $\mathbf{F}$ & $\mathrm{Db}$ & A & Bb \\
\hline$T_{g} P$ & $A b$ & G & B & $\mathrm{Eb}_{6}$ & E & C & $\mathrm{Bb}$ & D & Db & A & F & F* \\
\hline $\mathbf{T}_{\boldsymbol{7}} \mathbf{P}$ & A & Ab & C & E & $\mathbf{F}$ & Db & B & $E_{b}$ & D & Bb & Gb & G \\
\hline$T_{11} P$ & $C$ & C & E & $\mathrm{Ab}$ & A & $\mathbf{F}$ & $\mathrm{Eb}$ & G & $F$ & D & $\mathrm{Bb}$ & B \\
\hline $\mathbf{T}_{\mathbf{3}} \mathbf{P}$ & $\mathbf{F}$ & E & Ab & C & $C$ & A & $G$ & $B$ & $\mathrm{Bb}$ & Gb & $D$ & $\mathrm{~Eb}$ \\
\hline $\mathbf{T}_{2} \mathbf{P}$ & E & $\mathrm{Eb}$ & G & B & C & $\mathrm{Ab}$ & Gb & Bb & A & $\mathbf{F}$ & Db & D \\
\hline
\end{tabular}

Figure 2: Row chart

The 6-20 hexachord from which both these categories of aggregate are constructed is well-known for its high degree of symmetry, and the extraordinary number of ways by which it may be partitioned into transpositionally- or inversionallyrelated subsets. The ordered hexachord $\langle\mathrm{H}\rangle$, for example, can be partitioned into the two $\mathrm{I}_{11}$-related $[0,1,4]$ ordered trichords $\langle\mathrm{D}, \mathrm{D} b, \mathrm{~F}\rangle$ and $\langle\mathrm{A}, \mathrm{B} b, \mathrm{G} b\rangle$, an inversion relationship which is clearly expressed in the Motet's first statement of $\langle\mathrm{H}\rangle$ in bars $1-3$, both in the contour of the alto's melodic line and in its division into two halves by the rest in bar 2 . To list only a few, the 6-20 hexachord can also be partitioned into three $[0,1]$ (semitonal) dyads, or two $[0,1,5]$ trichords (in three different ways), or two $[0,4,8]$ augmented triads, or three overlapping $[0,1,4,5]$ tetrachords. Thus an aggregate constructed from two of these hexachords bears within itself certain compositional potentialities, arising from this capacity for subdivision into a wide variety of smaller units that can wrap around into, or be shifted onto, versions of themselves through transposition and/or inversion. In other words, such an aggregate is not simply a collection of twelve distinct musical tones, but a whole, constituted from a number of musical objects nested within one another and linked by various types of relationship. 
The significance of these properties of the 6-20 set class with respect to the text will emerge from the following more detailed pitch-structural analyses of the three passages discussed earlier: the opening section (bars 1-38, shown in Examples 2, 5, and 6), the soprano solo (bars 95-109, Example 3), and the homophonic closing phrase (bars 147-51, Example 4). These particular passages have been chosen because of their formal significance as, respectively, the Motet's beginning, its moment of most substantial textural (and textual) change, and its final closure.

\section{THE OPENING SECTION, BARS 1-38}

The opening section of the Motet subdivides clearly into three subsections. Subsection 1 (bars 1-10, Example 2) is structured around the A partitioning of the row, and subsection 2 (bars 11-21, Example 5) around the A1 partitioning. Each of these first two subsections is further subdivided on the basis of texture into an $a a b$ form, its first two phrases in an imitative two-voice texture (altotenor/bass-soprano in bars 1-6, and alto-bass/soprano-tenor in bars 11-18) and the third, a homophonic phrase for all four voices. Subsection 3 (bars 22-38, Example 6) engages both $A$ and $A 1$, and its textural structure is quite distinct from that of the earlier two subsections.

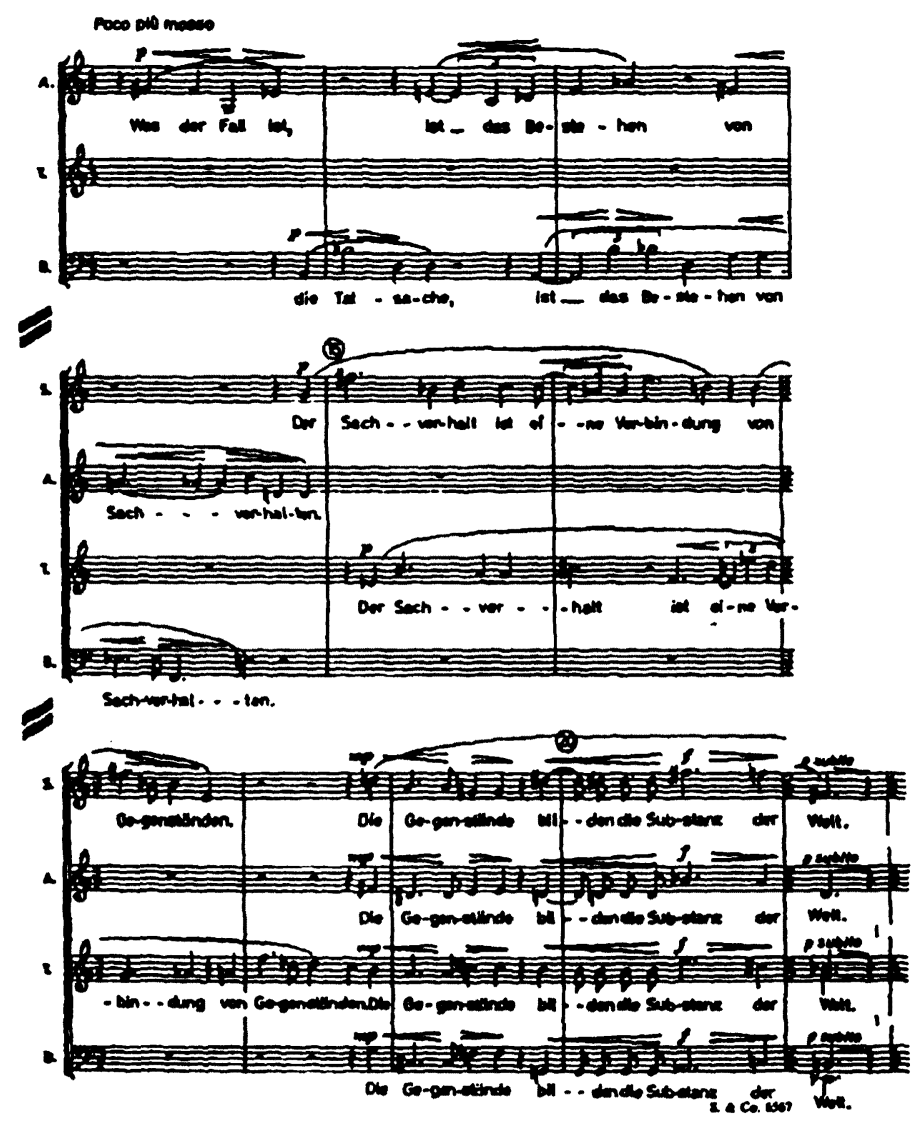

Example 5: Subsection 2, bars 11-21 

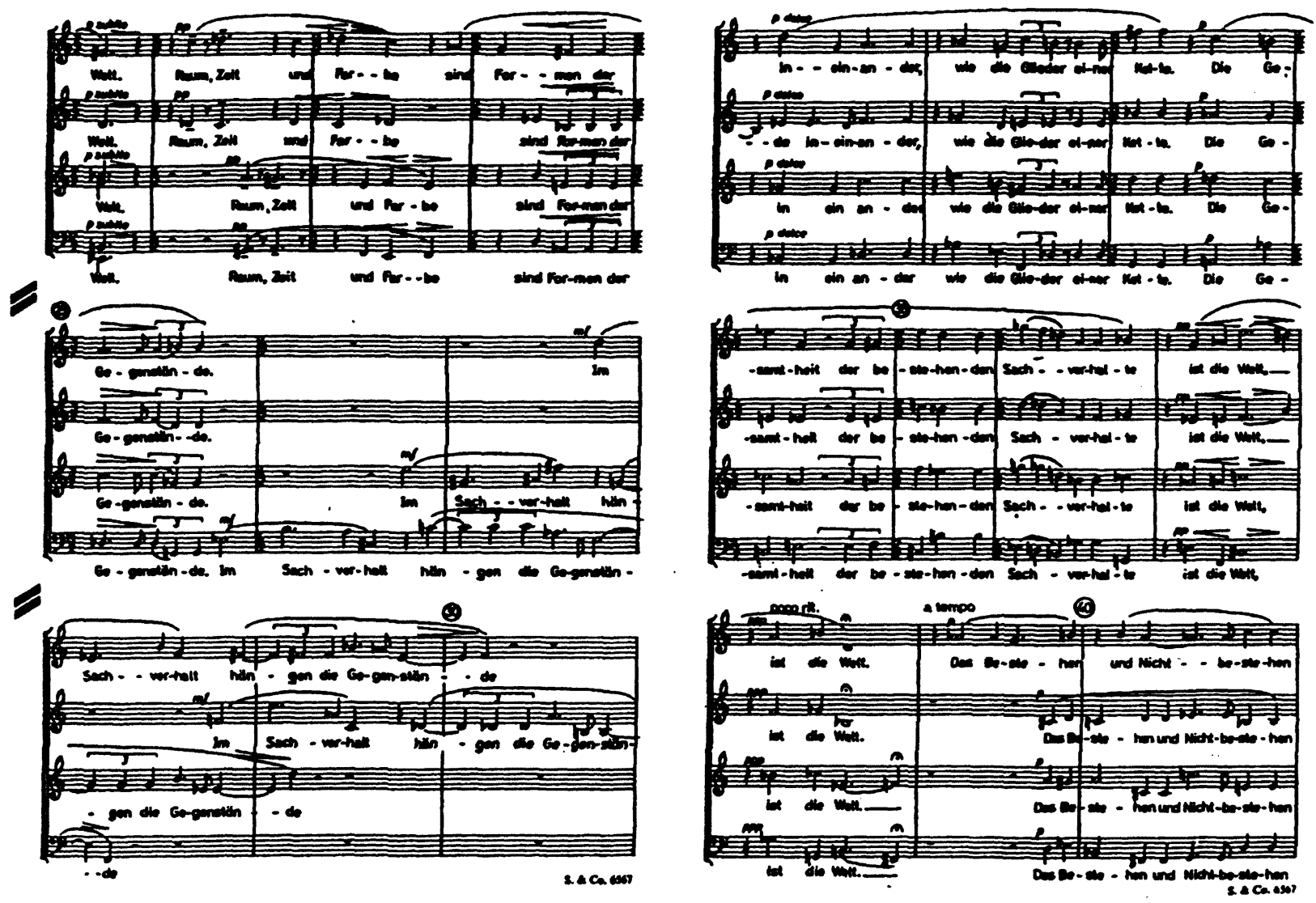


\section{Subsection 1 (Bars 1-10)}

The hexachordal and trichordal organization of the first two phrases has already been discussed in some detail. The third phrase (bars 7-10) represents a departure from the first two, in texture as well as pitch structure. Most obvious to the ear is the doubling of voice density, as all four parts sing together for the first time in a homophonic texture. With respect to pitch content, while each of the first two phrases presented a single statement of an $\langle\mathrm{H}, \mathrm{h}\rangle$ aggregate, the third phrase presents two tetrachordally-partitioned aggregates, followed by an additional 6-20 hexachord in the final measure. Figure 3 shows how the two partitionings of the aggregate in bars 7-9 relate to the hexachords $\mathrm{H}$ and $\mathrm{h}$.

Earlier, melodic hexachords were segmented into pairs of $[0,1,4]$ trichords; here, by contrast, six tetrachords are arranged in two groups of three, such that each group presents a statement of the aggregate. The arrangement of vertical tetrachords is palindromic at two levels: first, each aggregate consists of a central 4-21 $[0,2,4,6]$ tetrachord framed by two 4-19 [0,1,4,8]'s; second, the six tetrachords as a whole are palindromic under the inversion operation $\mathrm{I}_{9}$, as indicated by the arrows on Figure 3.

When changing from a trichordally- to a tetrachordally-based structure, the compositional problem arises of how to arrange the aggregate in such a way as to maintain the integrity of the hexachords, since four does not divide equally into six. Figure 3 shows Lutyens's solution: as indicated by the thin lines, the first and third tetrachords of each group of three originate from $h$ and $H$, respectively. The middle tetrachord puts the remaining two pitch classes of $\mathrm{H}$ in the centre, framed at the top and bottom by the two remaining pitch classes of $h$. Thus the two hexachords fit into each other like the pieces of a jigsaw puzzle. And although the pitch classes of each hexachord are distributed differently across the two aggregates, the shape of the "puzzle pieces" remains the same in both.

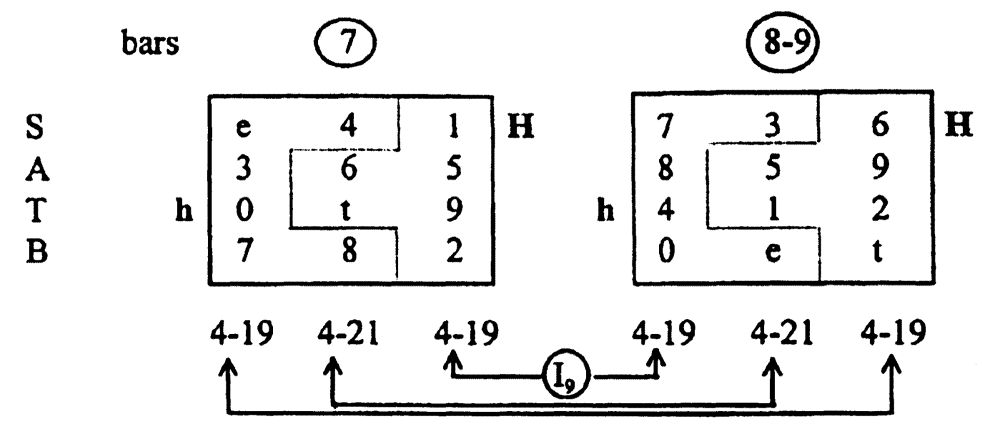

$$
\begin{aligned}
& C=0 \\
& t=10 \\
& e=11
\end{aligned}
$$

Figure 3: Aggregate structure, bars 7-9 
Because of the divisi alto and tenor parts, the chord which brings the first section to a close in bar 10 is a six-voice simultaneity, and we might reasonably expect it to originate in some way from one of the two hexachords that have structured the piece up to this point. But although this chord is indeed a 6-20 hexachord, it is a new one- $\mathrm{H} 1$-and it brings the section to a close not only with a new constellation of pitch materials, but with only half an aggregate. The completion of the aggregate begins in bar 11, as H1's complement, h1, initiates subsection 2, and the "early" arrival of $\mathrm{H} 1$ thus acts as a point of crossover between the two sections. This kind of overlap between text and pitch-class structural divisions is typical of Lutyens's transitions between segments.

\section{Subsection 2 (Bars 11-21)}

As noted earlier, subsection 2 resembles subsection 1 in its textural organization, but its pitch-class structure is based on the new, A1 partitioning of the aggregate into the hexachord pair $\{\mathrm{H} 1, \mathrm{~h} 1\}$. As in the first bar of the Motet, subsection 2 begins with a pair of inversionally-related $[0,1,4]$ ordered trichords, $\angle \mathrm{F} \#, \mathrm{G}, \mathrm{E} b\rangle$ and $\angle \mathrm{B}, \mathrm{B} b, \mathrm{D}\rangle$, but here the hexachord formed by these two trichords is no longer confined to a single voice, since the first trichord occurs in the alto, and the second in the bass. By contrast with subsection 1 , where each voice stated a single complete hexachord, subsection 2 initiates a more fluid partitioning of the aggregate, in which the pitch classes of a given hexachord are distributed between the active voices and therefore are not always heard as a consecutive series.

Figure 4 represents the pitch-class structure of the homophonic closing phrase of subsection 2 from the end of bar 18 to bar 21 , and comparison between Figures 3 and 4 shows the structural similarities and differences between the partitioning of the A and Al aggregates at the end of subsections 1 and 2. The six vertical tetrachords in bars 18-21 again display a palindrome of 4-19 and 4-21 tetrachords, as in bars 7-9 (although now involving $I_{7}$ ), and the shapes

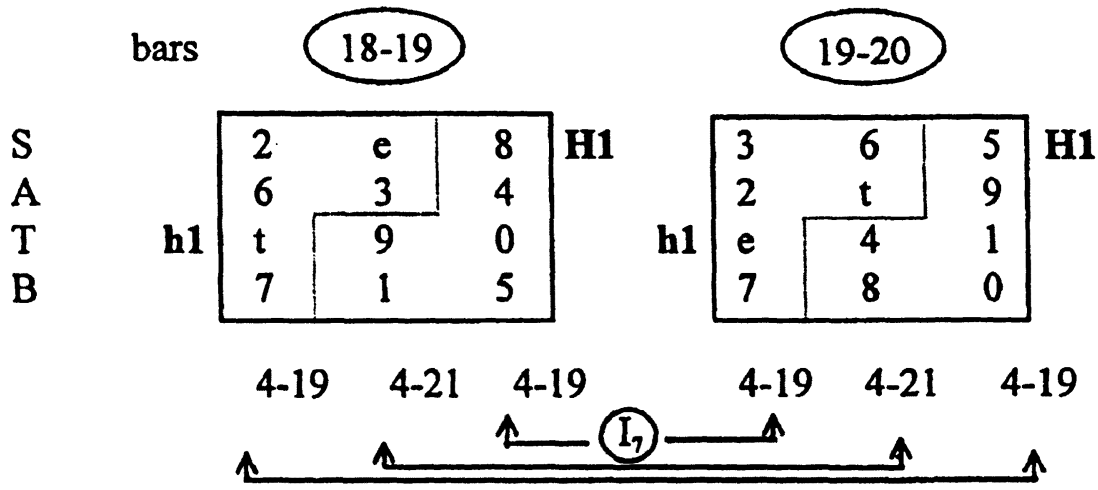

Figure 4: Aggregate structure, bars 18-20 
of the hexachordal puzzle pieces are the same in each aggregate, even though they are different in shape from those seen in Figure 3.

\section{Subsection 3 (Bars 22-38)}

The beginning of subsection 3 returns to the explicitly hexachordal structuring of subsection 1, but here the hexachords are partitioned differently. As shown in Figure 5, subsection 3 begins with the subdivision of $\mathrm{H} 1$, not into trichords, but into its three semitonal dyads $\{C, D b\},\{E, F\}$ and $\{G \#, A\}$. Each dyad is first presented as a simultaneity between two voices (soprano-alto or tenorbass), with subsequent voice exchanges yielding not only a series of shifting harmonic presentations of the dyad, but also a melodic pattern of neighbour motion within each voice, giving us both "vertical" and "horizontal" perspectives on the dyadic "object." Also of interest in this passage is the pairing of these dyadic objects in each measure into tetrachords, as indicated by the broken vertical line in Figure 5: the tenor and bass dyads $\{A, G \#\}$ in bar 22 , and $\{E, F\}$ in bar 23 , combine with the $\{C, D b\}$ dyad held constant in the soprano and alto parts to form two tetrachords of type $[0,1,4,5]$, or 4-7, which invert into one another under $I_{1}$, that is, around the $\{C, D$ b $\}$ dyad; a third 4-7 tetrachord $\{\mathrm{A}, \mathrm{G} \#, \mathrm{E}, \mathrm{F}\}$ is formed by the tenor and bass collectively. The tetrachordal segmentation of the aggregate carries through in the following bars, where linear ("horizontal") $[0,2,4,6] 4-21$ tetrachords form the basis of an imitative passage which lasts from the end of bar 25 until the middle of bar 31 . In bar 31, the texture becomes homophonic again, and is governed by "vertical" tetrachordal simultaneities until the end of the section in bar 38 .

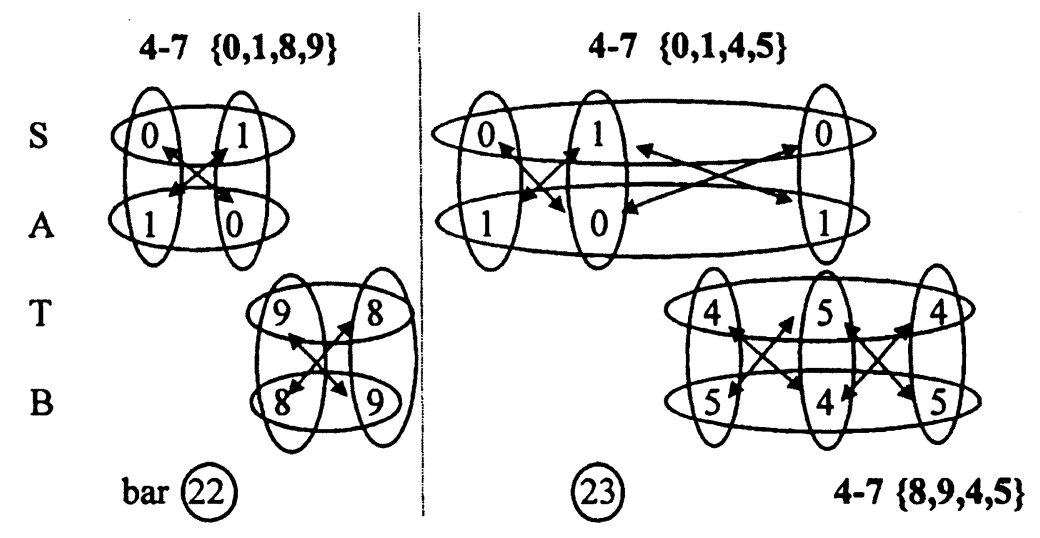

Figure 5: Bars 22-23

In this homophonic passage, the 4-7 tetrachord resumes its prominence, particularly in bars 33-36, as illustrated in Figure 6. But whereas in bars 22-23, the 4-7 tetrachords resulted from the combination of dyads, here they emerge as a result of the transpositional relations between four concurrently unfolding row forms, distributed across the four voice parts. That is, beginning in the middle of bar 33, the soprano, alto, tenor, and bass lines consist of $T_{10} P, T_{6} P$, 
$T_{11} P$, and $T_{7} P$, respectively. ${ }^{26}$ Since the first vertical tetrachord of the passage, $\{C, D b, A b, A\}$, is a member of set class 4-7, it follows from the homophonic texture binding these four T-related rows together that each of the next eleven vertical simultaneities will also belong to the set class 4-7.

This sinuous chain of verticalities binds together horizontally as well, as indicated by the arrows in Figure 6: the interval-class content of the 4-7 tetrachord and the intervallic sequence of the row relate such that each tetrachord holds two pitch classes in common with its predecessor, with the exception of the two central tetrachords. This "breaking point," indicated by the vertical dotted line, divides the passage into two halves, the first controlled by hexachords $\mathrm{H} 1$ and $\mathrm{H}$, and the second by their complements; the second is nevertheless palindromically linked by transposition to the first, as indicated by the solid arrows. Note also that the upper voices are paired by their singing of concurrent A-partitionings of the aggregate, and the lower, by their singing of concurrent A1-partitionings. Therefore, whereas the beginning of subsection 3 emphasized (through textural differentiation as well as pitch class organization) the smallest subgroups of the aggregate, that is, the semitone dyads and their combination into 4-7 tetrachords, this audibly contrasting passage uses the same tetrachords to present a lyrically integrated totality of the aggregate forms that structure the Motet.

\section{The Soprano Solo, Bars 95-109}

Example 3 reproduces the haunting soprano solo in bars 95-109, associated with the passage of the text in which Wittgenstein addresses that most profoundly personal and emotionally-charged of philosophical problems, the nature of death. As previously discussed, the solo begins with a monophonic statement of $\mathrm{T}_{0} \mathrm{P}$, which unfolds concurrently with its first complete sentence, "Wie auch im Tod die Welt sich nicht ändert, sondern aufhört" ("As also in death, the world does not change, but comes to an end"). But here, there is a notable contrast in melodic contour: where in bar 1, the alto began the Motet with a semitone descent from D4-Db4, here the soprano's D5 stretches upwards to $C \sharp 6$, marking the uppermost boundary of the Motet's pitch space. This steep 11-semitone ascent is nicely balanced at the end of the phrase by the 11-semitone descent from B4 to C4 in bars 99-100.

A second row form, $\mathrm{I}_{9} \mathrm{P}$, begins in bar 101 and again spans exactly one complete sentence. Because $P$ is hexachordally combinatorial under $I_{9}$, the $<\mathrm{H}, \mathrm{h}>$ ordering of the hexachords in bars $95-100$ is reversed in bars 101-3, resulting in the palindromic arrangement of unordered hexachords $<\mathrm{H}, \mathrm{h}, \mathrm{h}, \mathrm{H}\rangle$ over the two phrases.

The third complete sentence of the solo, "Den Tod erlebt man nicht," begins in bar 103, concurrently with the onset of the H1 hexachord $<A, A b, C, E, F, D b\rangle$, which seems to initiate the statement of a third row form, $T_{7} P$. The ordering of

26There is a slight deviation on the downbeat of bar 34, with an exchange of the pitch classes $\mathrm{E}$ and $\mathrm{C} b$ between the alto and tenor parts, possibly in order to ensure conjunct motion in the inner voices. However, this does not affect the pitch-class content of the vertical tetrachords. 


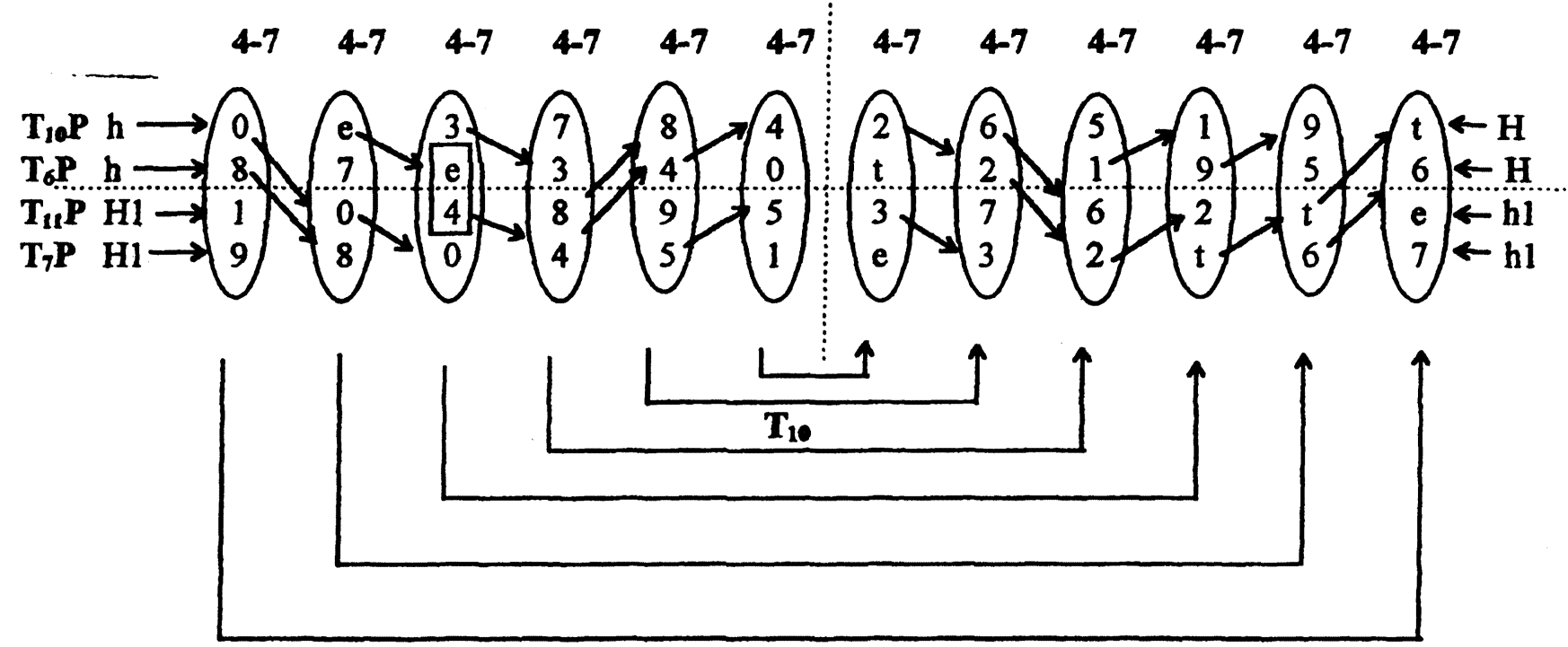


h1 that follows in bar 107 , however, is not $\mathrm{T}_{7} \mathrm{P}$ 's second hexachord $\langle\mathrm{B}, \mathrm{E} b, \mathrm{D}, \mathrm{B} b, \mathrm{G} b, \mathrm{G}\rangle$, but $\langle\mathrm{D}, \mathrm{E} b, \mathrm{~B}, \mathrm{G}, \mathrm{G} b, \mathrm{~B} b\rangle$. Even if we consider the twelve-tone series in bars 101-7 a variant of $T_{7} P$, such an interpretation would place the end of the row in the middle of the melisma on the word "ewig," with an "extra" hexachord tagged on to the end of the solo.

A more elegant interpretation is that the $\mathrm{H} 1$ hexachord in bars $101-3$ is a self-contained unit corresponding to a complete sentence of text, and that the following h1 hexachord in bar 107 functions as the beginning of a complete statement of the row form $\mathrm{I}_{4} \mathrm{P}$, which corresponds to the entire last sentence of the solo's text ("Der lebt ewig, der in der Gegenwart lebt"). This interpretation of the solo's serial structure captures the consistent relation between music and text in the passage, whereby complete melodic units in one domain map onto complete grammatical units (Sätze) in the other. The association of only a single hexachord with the third sentence conforms to the hexasyllabic length of the grammatical unit, but it also confirms the strong, often independent status of the hexachord in Lutyens's serial language.

\section{The Closing Phrase, Bars 147-51}

The final phrase of the Motet, reproduced in Example 4 and interpreted graphically in Figure 7, brings the piece to a hushed close. Comprised of a homophonic series of twelve tetrachordal simultaneities, the passage recalls bars 33-36 (shown in Figure 6) in its concurrent unfolding of four row forms, the uppermost of which (as noted earlier) is $\mathrm{T}_{0} \mathrm{P}$. Supporting the soprano's statement of $\mathrm{T}_{0} \mathrm{P}$ is a statement in the bass of $\mathrm{T}_{8} \mathrm{P}$, a transposition of the row which preserves the A partitioning of the aggregate. The alto and tenor parts collectively state row forms $T_{7} P$ and $T_{2} P$, but with considerable voice exchange between the two parts, as indicated by the boxes in Figure 7. Since this voice exchange does not affect the pitch class content of the chords, the simultaneous statement of the four row forms $\mathrm{T}_{0} \mathrm{P}, \mathrm{T}_{7} \mathrm{P}, \mathrm{T}_{2} \mathrm{P}$, and $\mathrm{T}_{8} \mathrm{P}$ results in a homogeneous harmonic texture, a series of twelve vertical simultaneities of set class $[0,1,5,7]$, or 4-16. The interval-class content of the 4-16 tetrachord and the intervallic sequence of the row relate such that, in this passage, all pairs of consecutive vertical tetrachords hold exactly one pitch class in common.

The pitch-class structural organization of this final phrase contributes to the achievement of closure for the Motet in a number of ways. For example, the closing 11-semitone descent from B4 to C4 imitates, both melodically and rhythmically, the closure of the first phrase of the soprano solo in bars 99-100. What is new in the ending of this closing phrase is the support of the soprano melodic line by the three remaining voices: the alto and tenor parts move in parallel motion with the soprano, descending 11 semitones to their final pitches, while the bass G2 moves upwards by semitone to A b2, effectively balancing the substantial leaps in the upper parts.

The reprise of the soprano solo's melodic material at the end of the Motet underscores a certain closural imperative implicit in the text of both passages. Cessation is foretold in bar 100 ("die Welt sich nicht ändert, sondern aufhört"), but enacted in bar 151, as the final proposition of the text- "Wovon man nicht 
Figure 7: Bars 147-51 (boxes indicate pitch class pairs whose positions are registrally switched in the score)

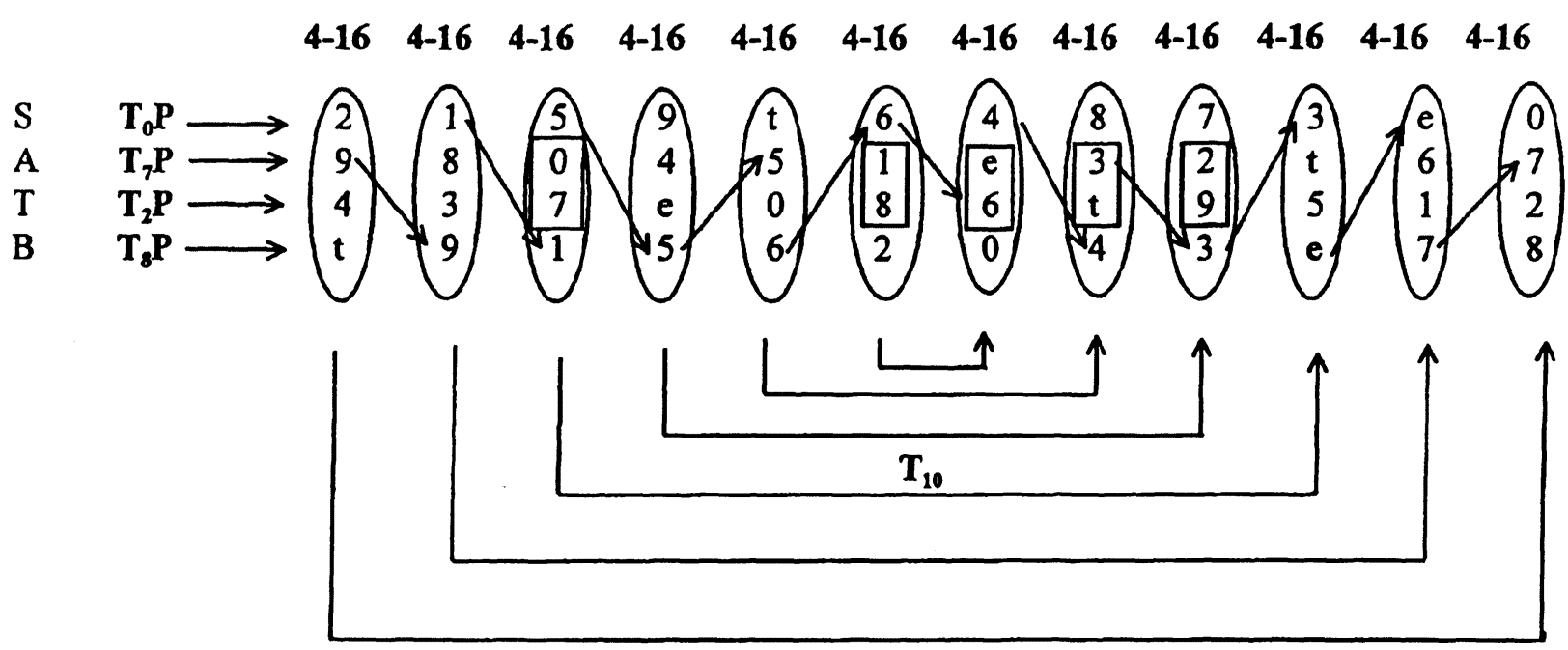


sprechen kann, darüber muss man schweigen" ("Whereof one cannot speak, thereof one must be silent")-calls for silence, virtually demanding closure. The sense of completion at this moment is strengthened by the "completion" of the solo's monophonic melody with the added harmonic dimension provided by the full homophonic complement of voices.

\section{RELATIONS BETWEEN MUSIC AND TEXT IN THE MOTET}

The world is all that is the case.

The world is the totality of facts.

Facts in logical space are the world.

What is the case, the fact, is the existence of atomic facts.

An atomic fact is a combination of objects.

Objects form the substance of the world.

Space, time and colour are forms of objects.

In the atomic facts objects hang one in another, like the links of a chain.

The totality of existent atomic facts is the world.

What potential for musical expression could a composer sense in this text? In what way does it ask to be interpreted musically in the same way as might a lyric by Heine or Mallarmé? But of course it does not, for from the order in which music and text were brought together in the composition of this Motet we know that Lutyens was not seeking to express in musical terms Wittgenstein's understanding of the external world. Rather, it seems more accurate to suggest that she perceived in Wittgenstein's text an analog of the musical world she herself was creating.

That is, if we conceive of Wittgenstein's "Welt" as a metaphor for the twelve-tone musical "world," we can see how fitting a choice of text the Tractatus really is, given Lutyens's long-standing fascination with serial composition. The totality of musical pitch space is divisible into its fundamental "atomic" units of the twelve pitch classes. As Wittgenstein's "Sachverhalten" consist of combinations of objects, we can conceive of musical "facts" as segments made up of multiple tones, combined and presented as ("vertical") simultaneities or ("horizontal") temporal contiguities, or associated according to any of the other segmentation criteria used in musical analysis. Wittgenstein writes that "Space, time and colour are forms of objects"; likewise, the objects from which musical "facts" are comprised exhibit varying properties with respect to musical pitch space, time, and "colour" (timbre), articulation, and so on. Notably, it is this proposition of the text that Lutyens associates with the passage illustrated in Figure 5, in which she presents the hexachord's dyadic "objects" in shifting melodic and harmonic forms. Furthermore, as exemplified in both Figures 5 and 6, musical objects often do indeed "hang one in another, like the links of a chain."

Not only the content of the text, however, suggests the idea of musical linkage, but also the text's own sonic organization. Figure 8, for example, identifies through the use of brackets several words or phrases-"text motives," as it were-which recur throughout the passage in their original or in varied form. Performing this text aloud suggests the aural salience of these recurring words and phrases, analogous to the hexachordal, tetrachordal, trichordal, and 
$1 \quad \int_{\text {Die Welt ist alles, was der Fall ist. }}^{\mathbf{W}} \Gamma^{\top} \underset{7}{\mathbf{F}}$

$2 \quad\left[\begin{array}{l}\mathbf{W}\rceil \\ \text { Die Welt ist die Gesamtheit der Tatsachen. }\end{array}\right.$

$3 \quad$ Die Tatsachen im logischem Raum sind die Welt.

$4 \quad$ Was der Fall ist, die Tatsache, ist das Bestehen von Sachverhalten.

$5 \quad$ Der Sachverhalt ist eine Verbindung von Gegenständen.

$6 \quad$ Die Gegenstände bilden die Substanz der Welt.

$7 \quad \begin{aligned} & \mathbf{R}\rceil \\ & \text { Raum, Zeit und Farbe ... sind Formen der Gegenstände. }\end{aligned}$

$\Gamma \mathbf{S}\rceil$ GS 7

8 Im Sachverhalt hängen die Gegenstände ineinander, wie die Glieder einer Kette.

9 Die Gesamtheit der bestehenden Sachverhalte ist die Welt.

Text Motives: $\mathbf{W}=$ "(die, der) Welt"; $\mathbf{F}=$ "Was der Fall ist"; $\mathbf{T}=$ "Tatsache(n)";

$\mathbf{S}=$ "Sachverhalt(en)"; $\mathbf{G}=$ "Gesamtheit"; $\mathbf{R}=$ "Raum"; $\mathbf{B}=$ "Bestehen(den)";

GS $=$ "Gegenstände(n)"

Figure 8: Text structure, lines 1-9

dyadic "links" from which Lutyens constructed the musical form of the Motet. Therefore, Wittgenstein's text (particularly in the telescoped version "composed" by Lutyens herself) does not simply explain in words her musical world, it re-presents it, in another sonic structure which is perhaps as musical in its own way as a lyric by Heine or Mallarmé.

\section{CONCLUDING REMARKS}

The concept of music as representation, of text or idea, is an old and muchdiscussed problem in musical scholarship. The concept of text as representation of music, on the other hand, has been addressed much less frequently. Writers, particularly but by no means exclusively poets, have long sought to engage the "musical," or at least sonic, properties of language. In twentieth-century English literature alone one could cite as examples Gerard Manley Hopkins in poetry, James Joyce in the novel, Harold Pinter in drama. Writers who have also theorized about the potential of language to emulate music's relational 
structure include Stephane Mallarmé, and the late nineteenth-century experimental Russian novelist Andrey Bely. ${ }^{27}$

All of these examples involve the engagement of the sonic or structural properties of music in general, in the creation of a literary work. But this is not the same as the idea which this article has explored, namely, that in certain cases a text can be considered as a representation of a particular, pre-existing musical structure. This idea can be found, however, in the musical criticism and practice of Friedrich Nietzsche. Nietzsche's love of music is well-known, particularly as a result of his personal relationship with, and writings on, Richard Wagner. But he was also himself a composer, and was known, after having completed the music for a song, to ask his friends for help in finding an appropriate text. ${ }^{28}$ Nietzsche insisted that "a musical excitement that comes from altogether different regions chooses the text of this song as a metaphorical expression of itself.... The poem is only a symbol and related to the music like the Egyptian hieroglyph of courage to a courageous soldier." 29 The case that, in the realm of classical Western art music, we have come to think of as "normal," in which a composer designs a musical structure in order to enhance the expression of a pre-existing text, thus represents only one end of a continuum of possible relations between music and text. Closer to the other end, at which text serves as a representation of the musical structure, are works such as the Wittgenstein Motet. In between the two extremes, there is a whole spectrum of alternative ratios of influence that can hold between music and text; furthermore, there is nothing to say that these ratios must remain constant throughout the course of a given work.

Text can represent music, then, to the same degree that music can represent text: each carries within itself elements of the other, pointing back to their common origin as acts of composition. The barrier between music and text is less a solid wall than a permeable membrane, and analytical discussions of the relations between the two are richer when we acknowledge the fluidity of the influences which pass between them, in both directions.

In the BBC radio tribute broadcast after Elisabeth Lutyens's death in 1983, William Glock remarked about the Motet, which he himself had commissioned thirty years earlier:

27See, for example, Mary Breatnach's discussion of Mallarmé's musical aesthetic in Boulez and Mallarmé: A Study in Poetic Influence (Aldershot: Scolar Press, 1996), and Andrey Bely, The Dramatic Symphony/The Forms of Art, trans. Roger Keys and John Elsworth (Edinburgh: Polygon Books, 1986). Bely entitled his novels "symphonies," constructing them out of numbered sentences that he considered analogous to musical leitmotifs.

28Curt Paul Janz, in his edition of Friedrich Nietzsche, Der musikalische Nachlaß (Kassel: Bärenreiter, 1976), 327.

29Friedrich Nietzsche, "On Music and Words," trans. Walter Kaufmann, in Carl Dahlhaus, Between Romanticism and Modernism: Four Studies in the Music of the Later Nineteenth Century (Berkeley: University of California Press, 1980), 112. Nietzsche's privileging of music over text is dealt with critically by Richard B. Kurth in "Music and Poetry, A Wilderness of Doubles: Heine-NietzscheSchubert-Derrida," 19th-Century Music 21, no. 1 (Summer 1997): 3-37. 
The piece is marked semplice, an ideal but essential condition in trying to achieve a balance between its impersonal aspect and its illustrative aspect, a kind of geometry answering to Wittgenstein's philosophical thought. The text is illumined all the way through with unfailing invention, but if one can put it in such a way, the light remains constant. ... In [the Motet and in Quincunx], discipline and imaginative freedom intertwine, as they do to perfection, for example, in the canons from Bach's Musical Offering. ${ }^{30}$

Glock's "intertwining" of "discipline and imaginative freedom" is a fitting characterization of Lutyens's oeuvre, as analysis of works from different stages in her career quickly reveals. The Motet is one of the most tightly structured of her twelve-tone works, recalling the formative influence of Webern's cantatas. Far from being a dogmatic serialist, however, Lutyens seems to have approached each new composition with fresh ideas, using twelve-tone techniques as starting points for musical expression rather than as ends in themselves.

Anthony Payne, speaking in the same broadcast as Glock, remarked that "listening to Elisabeth Lutyens's Music for Orchestra IV, some little time after her death, provokes some melancholy reflections about the flimsy connection between artistic excellence and personal success." 31 In the final pages of her autobiography, Lutyens herself wrote that her one regret was that her music had not "contributed its quota, as I would have wished, to the interest and pleasure of more people." 32 With the release in 1993 of the first CD entirely devoted to Lutyens's compositions, and single compositions represented in various additional $C D$ recordings, this will perhaps begin to change..$^{33}$ Unfortunately, however, although the Wittgenstein Motet is occasionally still performed, it is not among these recent recordings. Hopefully, before too long, this also will have changed.

\section{Abstract}

Although Elisabeth Lutyens (1906-83) was a pioneer of British twentieth-century music, her work is relatively unknown in North America. This article begins with an introduction to her life and compositions, before going on to a detailed analysis of text-music relations in selected passages of her Motet, op. 27 (1953). The analysis forms the basis for a discussion of the concept of text as representation of music: Lutyens began to compose the music of the Motet first, and chose its text-excerpts

30 Glock, "Tribute to Elisabeth Lutyens," fol. 220.

31 Payne, "Tribute," fol. 225.

$32 A G B, 317$.

33 Elisabeth Lutyens (1906-1983), Jane's Minstrels, Jane Manning, soprano, Roger Montgomery (NMC D011). Other recorded works available on CD include the oboe quartet Driving Out the Death, op. 81 (1971), British Chamber Music for Oboe and Strings, Redcliffe Ensemble, Redcliffe Recordings RR 006; the Stevie Smith Songs (1948-53), on the CD Dreamscapes, Meriel Dickinson, mezzo-soprano, and Peter Dickinson, piano (Unicorn-Kanchana DKP(CD) 9093); and the song "As I Walked Out One Evening" (Auden), In Praise of Woman: 150 Years of English Women Composers, Anthony Rolfe Johnson, tenor, and Graham Johnson, piano (Hyperion CDA66709). 
from the Tractatus logico-philosophicus (1921) by the Austrian-born English philosopher Ludwig Wittgenstein (1889-1951)-because it seemed a fitting expression of the musical ideas that had already begun to develop. 